original base at Camaná, and Paul Tolstoy, continuing David Kelley's far north coast survey begun last year, is already working out of Piura. The material from last year's work is now being worked up and correlated at the San Marcos University Museum, and several preliminary findings are already in publication.

The new museum at the site of Puruchucu, $11 \mathrm{~km}$. east of Lima, was scheduled to open the 15th of October. Puruchucu itself is a small, self-contained site, typical of the epoch of Kingdoms and Confederations on the Central Coast, which was recently restored by Arturo Jimenez Borja. The accompanying museum has been designed to contain archaeological and physical anthropological specimens from this and similar excavated or restored sites in the vicinity of Lima. The initial collections include those from Puruchucu itself and the adjoining Huancho site of Encalada, those from the recent Ministry of Education excavations at the Vásquez site near La Molina, and those excavated by Louis M. Stumer at the Huaquerrones site on the Hacienda Vista Alegre. Jimenez Borja's work of excavating, cleaning, and restor- ing the Huaca Pan de Azúcar in San Isidro, Lima, is continuing with the cooperation of the Direccion de Arqueología e Historia and the Municipalidad de San Isidro. A rather long continuous occupation has been disclosed, with a part, at any rate, of the construction of a huaca dating from the Maranga culture, the latest specimens being of the Inca-associated style. Unusual and noteworthy is the relatively high incidence of specimens imported from or imitative of the late periods in the Cañete and Chincha valleys.

The second National Historical Congress, held at Lima, ended August 9th. The Congress was devoted to the pre-Columbian period and therefore there were present a good number of non-Peruvian anthropologists and archaeologists, both North American and European. The Congress concluded with a visit to current or recent archaeological excavations in the vicinity of Lima and another to the fortress of Paramonga and archaeological sites en route.

Assembled by G. ReICHel-DolmatofF

\title{
ANNOUNCEMENT OF THE ANNUAL MEETING
}

The 24th Annual Meeting of the Society for American Archaeology will be held April 30, May 1 and 2 at Salt Lake City, Utah, with the University of Utah as host institution. The formal sessions will meet in the University of Utah Union Building; arrangements are being made for accommodations at the Utah Hotel. Special activities include a tour of the University of Utah Press, printer of AmErican Antiouity, and on the last day of the meeting, a field trip on the late Pleistocene and recent geology of the Salt Lake region conducted by Daniel J. Jones of the University of Utah Geology Department.

James H. Gunnerson is Program Chairman, Dee Ann Suhm, Chairman of the Local Arrangements Committee. Send titles of papers to be presented at this meeting and brief ( 100 to 200 words) abstracts before April 1, 1959, to: James H. Gunnerson, Department of Anthropology, University of Utah, Salt Lake City 12, Utah.

The 25th Annual Meeting of the Society for American Archaeology will be held in the spring of 1960 at New Haven, Connecticut, with Yale University the host institution. The Executive Committee hopes to be able to continue to select the meeting place two years in advance. Members are advised that the attendance at the Salt Lake City meeting will strongly influence the Executive Committee in its consideration of future meeting places in the far west. 